\title{
Detection of Taura Syndrome Virus (TSV) in Litopenaeus vannamei in the Philippines
}

\author{
Joseph Carlo V. Vergel ${ }^{1,3}$, Lara Denise P. Cabawatan², Vivien Alexandra C. Madrona ${ }^{2}$, Abigail Flor T. Rosarioº, \\ Jean Beatriz M. Sta. Ana ${ }^{2}$, Maria Violeta R. Tare ${ }^{3}$, Mary Beth B. Maningas ${ }^{1,2,3 *}$ \\ ${ }^{1}$ The Graduate School, University of Santo Tomas, España, Manila, 1015, Philippines \\ ${ }^{2}$ Department of Biological Sciences, College of Science, University of Santo Tomas, España, Manila, 1015, Philippines \\ ${ }^{3}$ Research Center for the Natural and Applied Sciences, Thomas Aquinas Research Complex, University of Santo Tomas, \\ España, Manila, 1015, Philippines
}

\begin{abstract}
A B S T R A C T
Farming of Litopenaeus vannamei in the Philippines was seen as a measure to increase shrimp production in the country. Taura Syndrome Virus (TSV) is a viral pathogen reported to be associated with Litopenaeus vannamei and other shrimp species. TSV outbreak impedes the production of Litopenaeus vannamei population and other species susceptible to the virus. Detection of TSV in L. vannamei in the Philippines calls for proper mitigation and appropriate actions for aquaculture and environmental management towards sustainable development. This study embarked on the detection of TSV using a purposive sampling method. Samples showing morphological symptoms of TSV such as redness of the carapace and pleopods and necrotic gill tissue collected from sites in Luzon and Visayas in the Philippines were processed. Viral RNA was extracted from the gills, the central area of infiltration and replication site of the virus. Complementary DNA (cDNA) was synthesized from the RNA templates and were subjected to RT-PCR under specific conditions using TSV specific primers against a positive control. Selected sites in the Philippines were proven to be positive of infection as they showed morphological symptoms and RT-PCR result in having a band at around 200 base pairs (bp). Percentage of prevalence results were obtained: Bulacan with 5 out of 15 samples (33\%), Batangas with 7 out of 15 samples (47\%), Bohol with 1 out of 15 samples (7\%) and Cebu with 2 out of 15 samples (13\%). The Batangas samples showed the highest prevalence of $47 \%$ (7 out of 15 samples) that were positive of the infection. This study reported the presence of TSV in L. vannamei in the country using morphological and molecular techniques.
\end{abstract}

E-mail address: mbmaningas@ust.edu.ph*/ marybethmaningas@gmail.com*

Received: September 14, 2018

Accepted: January 28, 2019
Keywords: Taura Syndrome Virus, Molecular diagnostics, Pacific white shrimp

\section{I N T R O D U C T I O N}

S everal diseases caused by different viruses were found to affect the health and successful population growth of shrimps in the Pacific area. Some of these are White Spot Syndrome Virus (WSSV), Yellow Head Virus (YHV), Infectious Hypodermal and Haemapoietic Necrosis Virus (IHHNV), Hepatopancreatic parvovirus (HPV), Monodon Baculovirus (MBV), Laem-Singh Virus (LSNV), Mourilyan Virus (MoV), and Taura Syndrome Virus (TSV) (Lightner 1999). Testing and research in the Philippines revealed positive results for WSSV (Magbanua et al. 2000); YHV (Albaladejo et al. 1998); IHHNV (Caipang et al. 2011); HPV (Catap et al. 2003); MBV (Natividad et al. 2006), however some including the TSV have yet to be detected as stated in the NACA, OIE, and FAO quarterly animal disease report of 2018. Studies and articles have been published regarding the presence of the virus in neighboring countries such as Burma (Myanmar), China, Indonesia, Thailand, and Vietnam (NACA, OIE, FAO, 2019). According to a study by Kautsky et al. (2000), the cause behind the development and spread of pathogens in shrimp aquaculture was said to be mostly because of the cultural intensity and high stocking densities and uncontrolled movement of broodstocks and postlarvae. This study aims to detect the presence of TSV in the Philippines.

Taura syndrome virus (TSV), a small picorna-like RNA virus that has been classified in the new 
family Dicistroviridae, was first reported as a severe cause of shrimp mortality in reared Litopenaeus vannamei, a penaeid shrimp also known as the Pacific White Shrimp and the White Leg Shrimp. It spread principally through the regional and international transfer of live postlarvae and broodstock. Subsequently, through the importation of infected broodstock, TSV outbreaks spread to Asia, first to Taiwan and China and then to Thailand, Indonesia, and Korea (Sappat et al. 2011). Taura syndrome (TS) is a disease of the nursery phase of L. vannamei. It usually occurs within 14-40 days of stocking postlarvae into grow-out ponds or tanks with a mortality of $95 \%$. TSV can persist outside a host and retain infectivity at experimental temperatures between $0^{\circ} \mathrm{C}$ and $121^{\circ} \mathrm{C}$ (Wertheim et al. 2009). Transmission is horizontal through ingestion. Although vertical transmission is suspected, it has not been demonstrated. Migratory birds, aquatic insects, and humans are likely mechanical vectors of the disease. Individuals surviving the chronic phase of Taura syndrome are thought to be carriers of the virus. The virus can be detected using various methods such as Loop Mediated Isothermal Amplification (LAMP) (Sappat et al. 2011). However, confirmatory tests were done using RT-PCR reactions under specific conditions and with the use of gene-specific primers because of its high specificity and sensitivity. Here we report the detection of TSV for the first time in the Philippines. Proper mitigation and regulation procedures must be done to prevent possible massive losses of the shrimp aquaculture industry in the country.

\section{MATERIALS AND METHODS}

Fifteen (15) samples of L. vannamei species were obtained from each of the sites chosen: Bulacan, Batangas, Bohol, and Cebu, Philippines. Purposive sampling was employed using shrimps with apparent morphological symptoms. Symptoms include pleopods being uncharacteristically red compared to that of uninfected shrimp, the gill tissues showing necrosis, and overall redness of the external appearance (Figs. 1-3). RNA was extracted from the gills of the shrimp samples. A ratio of 1:3 (1 part of gills for 3 parts of TRIzol $^{\text {Tw }}$ reagent, Invitrogen) was used for the extraction process. About $30-80 \mathrm{mg}$ of gills were placed in $1.5 \mathrm{~mL}$ microcentrifuge tubes with $300 \mu \mathrm{l}$ TRIzol reagent. Total RNAs were synthesized into cDNAs using SuperScript ${ }^{\oplus}$ III Reverse Transcriptase (Life Technologies - Invitrogen ${ }^{\mathrm{Tw}}$ ) based on the manufacturer's instruction. Primers used for the detection of TSV were: TSVF5'-AAGTAGACAGCCGCGCTT-3' and TSVR5'-TCAATGAGAGCTTGGTCC-3' with the following conditions: initial denaturation of $95^{\circ} \mathrm{C}$ for $5 \mathrm{~min}, 28$ cycles of denaturation at $95^{\circ} \mathrm{C}$ for $30 \mathrm{sec}$, annealing at $55^{\circ} \mathrm{C}$ for $30 \mathrm{sec}$, extension at $72^{\circ} \mathrm{C}$ for $1 \mathrm{~min}$ with final elongation of $72^{\circ} \mathrm{C}$ for $10 \mathrm{~min}$. $9992 \mathrm{~F}$ and 9195R amplify a 231 bp sequence of the TSV genome. The fragment that was amplified is from a conserved sequence which is located in the intergenic region and ORF 2 of TSV. Primer 9992F is located near the 3' end of the intergenic region, and $9195 \mathrm{R}$ is located on ORF2 within VP2/CP1. Nunan et al. (1998) developed the primers for TSV detection, and the World Organization for Animal Health (OIE) has adopted the primers as the basis for TSV detection among shrimp populations worldwide. Purified RT-PCR products were sequenced (Macrogen, Korea), assembled, and aligned using Codon Code Aligner and ClustalW respectively with other TSV viral isolates that were found to have homology with the TSV Philippine isolate based on BLASTn search. Sequence similarity was inferred by using the Maximum Likelihood method based on the Tamura-Nei model (Tamura 1993). Phylogenetic tree(s) for the heuristic search were obtained by applying the Neighbor-Joining method to a matrix of pairwise distances estimated using the Maximum Composite Likelihood (MCL) approach. The analysis involved eight (8) nucleotide sequences. All positions containing gaps and missing data were eliminated. Evolutionary analyses were conducted in MEGA6 (Tamura 2013). Japanese encephalitis virus strain T1P1-S1 served as the outgroup. The TSV Philippine isolate DNA sequence was deposited in the DNA Databank of Japan (DDBJ).

\section{RESULTS AND DISCUSSION}

Shrimp samples were chosen based on the visible symptoms of TSV infected shrimp. There were red spots observed and a general redness of the carapace of the collected shrimp samples. The pleopods were uncharacteristically red compared to that of uninfected shrimp, and the gill tissues show necrosis, which showed that the samples were infected with TSV based on external appearance (Figs. 1-3). Further processing using RT-PCR and phylogenetic techniques were used to confirm the presence of the virus. External symptoms of TSV-infected shrimps include the expansion of red chromatophores giving the affected shrimp an overall pale reddish coloration and making the tail fan and pleopods distinctly red in the acute stage of infection (Phalitakul et al. 2006) which 
Table 1. Primers labeled as 9992TSVF and 9195TSVR were used to detect TSV among samples from Bulacan, Batangas, Cebu, and Bohol, Philippines. $\beta$-actinF and $\beta$-actinR were used as controls.

\begin{tabular}{|lccc|}
\hline \multicolumn{1}{|c|}{ Primer Name } & Oligonucleotide Sequence & $\begin{array}{c}\text { Expected } \\
\text { product sizes }\end{array}$ & Sources \\
\hline 9992 TSV F & 5'-AAGTAGACAGCCGCGCTT-3' & 231 bp & OIE, 2016 \\
9195 TSV R & 5'-TCAATGAGAGCTTGGTCC-3' & & \\
$\beta$ - actin F & 5'-AACTCCCATGACATGGAGAACATC-3' & 150 bp & Maningas, 2008 \\
$\beta$ - actin R & 5'-TCTTCTCACGGTTGGCCTTG-3' & & \\
\hline
\end{tabular}

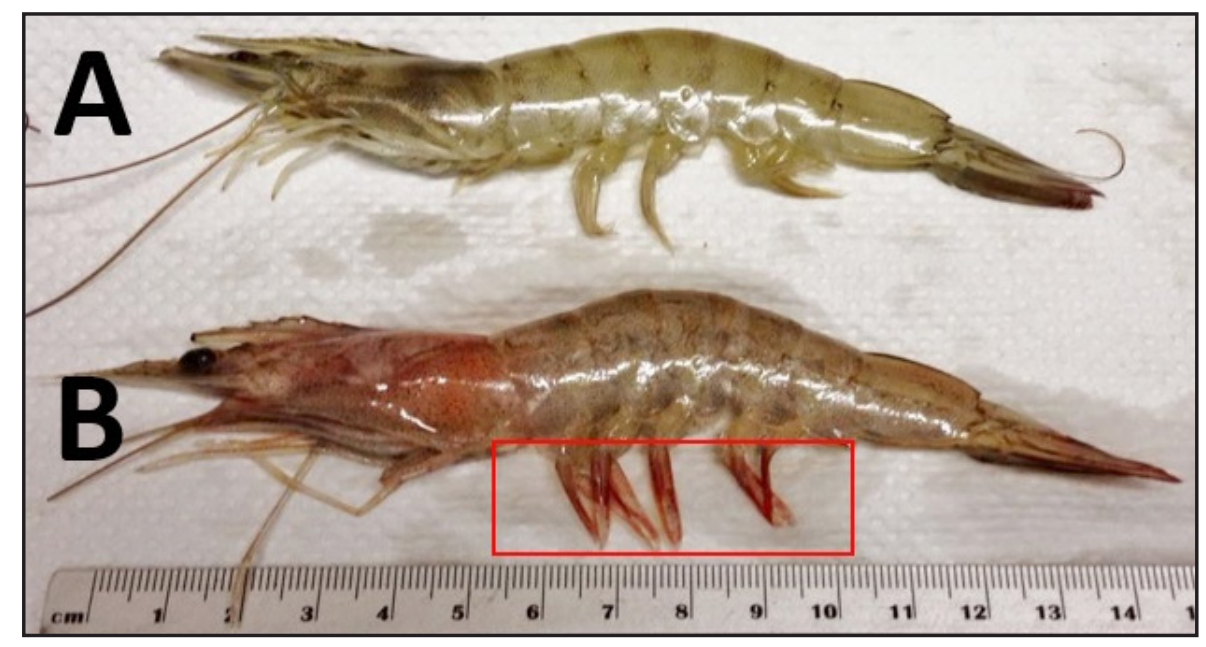

Figure 1. Samples comparing an uninfected shrimp (A) with an infected shrimp (B) having a general redness of the carapace and pleopods.

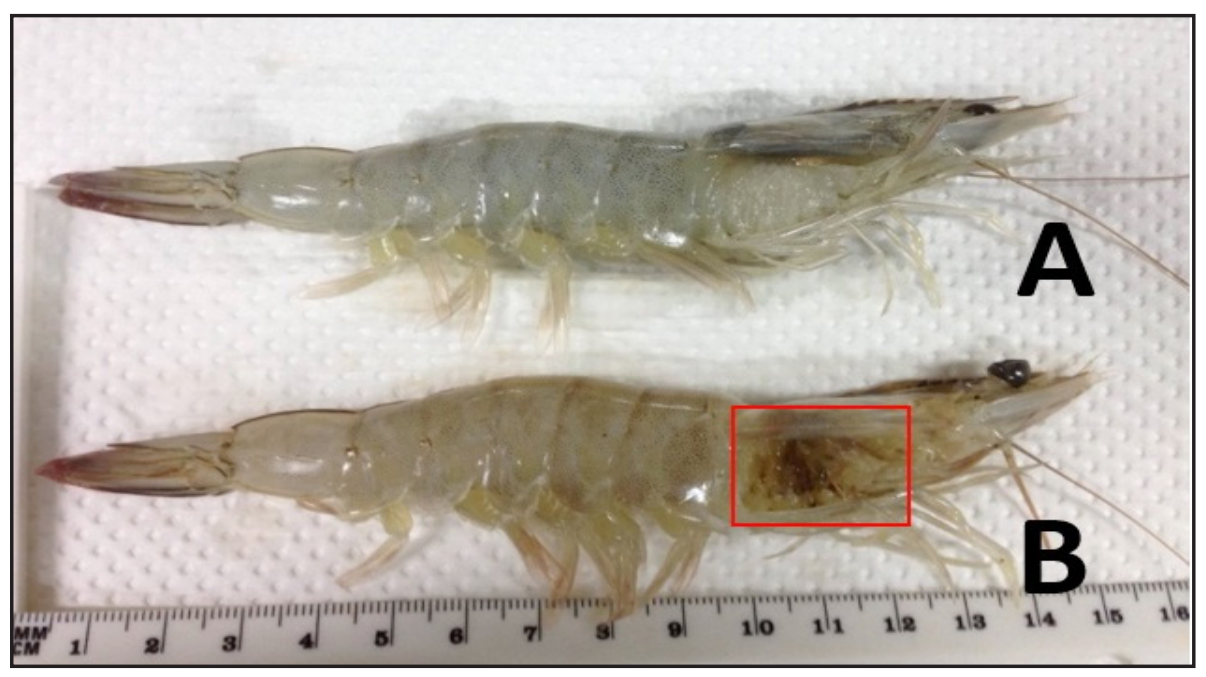

Figure 2. While in the transition phase of infection, random, multifocal, and irregularly shaped melanized, cuticular lesions are seen on the carapace $(B)$. 


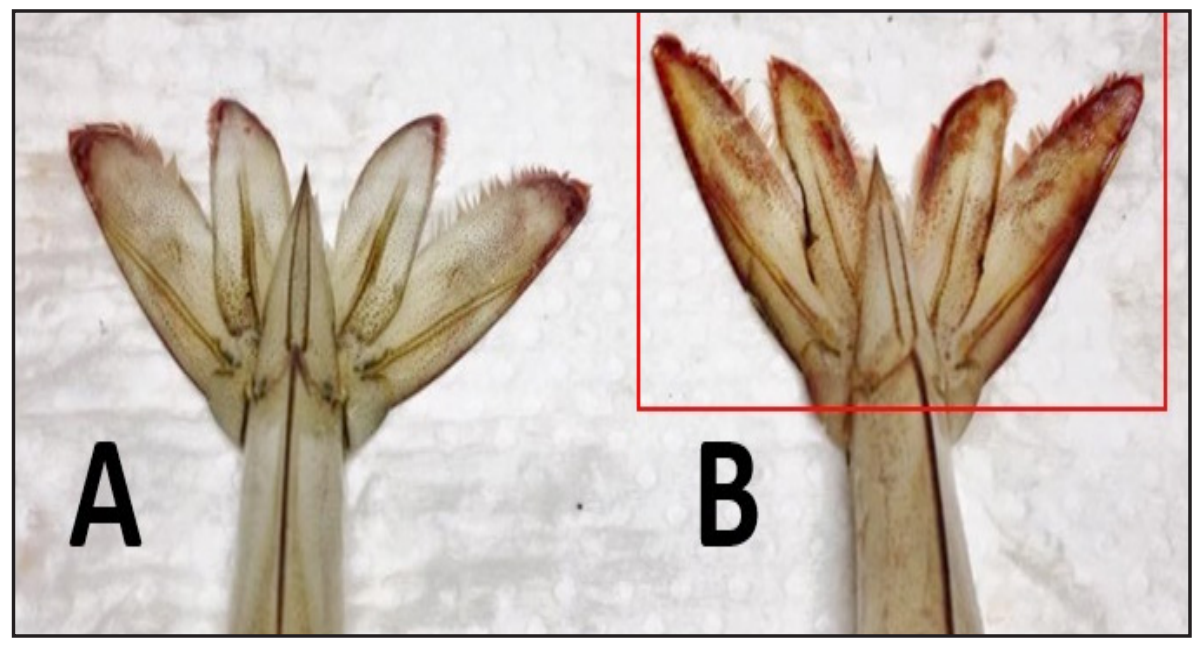

Figure 3. Samples showing the tail fans of an uninfected shrimp (A) compared to an infected shrimp (B) wherein the whole structure is red in appearance.

can be observed in Figures 1 and 3. While in the transition phase of infection, random, multifocal, irregularly shaped melanized cuticular lesions are seen on the carapace. Gill tissues were used in the confirmatory test because the virus is shown mainly to infect and target cuticular epithelium and subcutis of the foregut, gills, appendages, body cuticle, and hindgut (OIE 2016).

The study by Nunan et al. (1998) and the World Organization for Animal Health (OIE) recommended the RT-PCR procedure. The same procedure was employed in this study, and samples showed positive results for TSV (Fig. 4). BLASTn search results show that the TSV sequences from the Philippines have very high sequence similarity at 86 $100 \%$ with TSV viral isolates from other countries, namely Taiwan, Thailand, Venezuela, USA, Colombia, and Belize. The TSV Philippine isolate DNA sequence was deposited in the DNA Databank of Japan (DDBJ) with accession number (LC482506). Construction of a phylogenetic tree using the Maximum Likelihood method of the viral isolates sequences from the said countries along with that of the Philippines' revealed very close similarity between the Philippines and that of Taiwan isolate (Fig. 5). Consistent with the study of Wertheim et al. (2009) where TSV isolates from
China, Taiwan, and Thailand group to the Southeast Asian TSV lineage, one of the four major TSV lineages. The close similarities of the two strains may be the result of a single introduction from both countries (Philippines and Taiwan), wherein both strains are descendants of a single recent common ancestor.

Percentage prevalence results were obtained

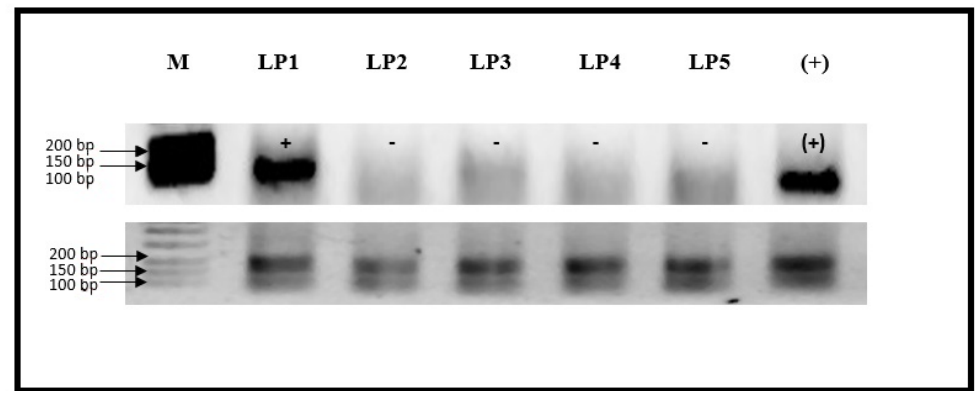

Figure 4. RT-PCR analysis of Taura syndrome virus from shrimp samples in the Philippines: LP1, LP2, LP3, LP4, and LP5. LP1 was confirmed to be TSV positive. Positive template (+) serves as the positive control. $\beta$-actin served as control at $150 \mathrm{bp}$.

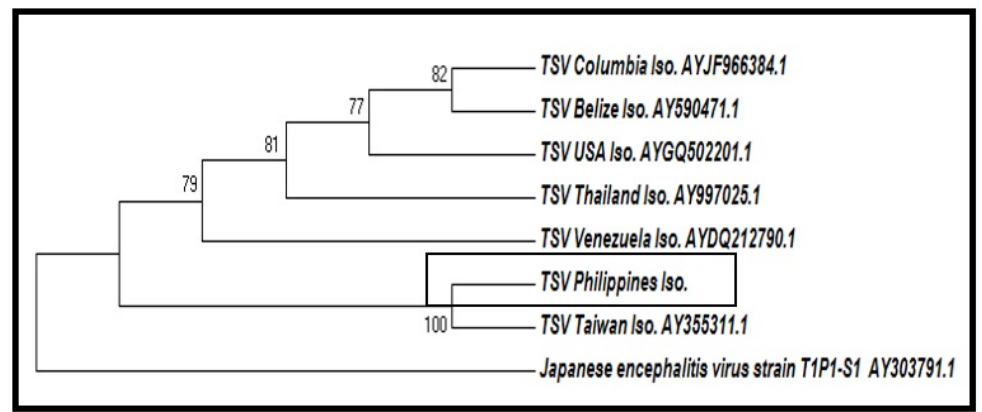

Figure 5. Sequence analysis of TSV Philippine isolate (LC482506) was aligned, and phylogenetic analysis was done together with the other isolates of the virus. TSV Philippine isolate was found to be closely related to TSV Taiwan isolate. Japanese encephalitis virus strain T1P1-S1 served as the outgroup. 


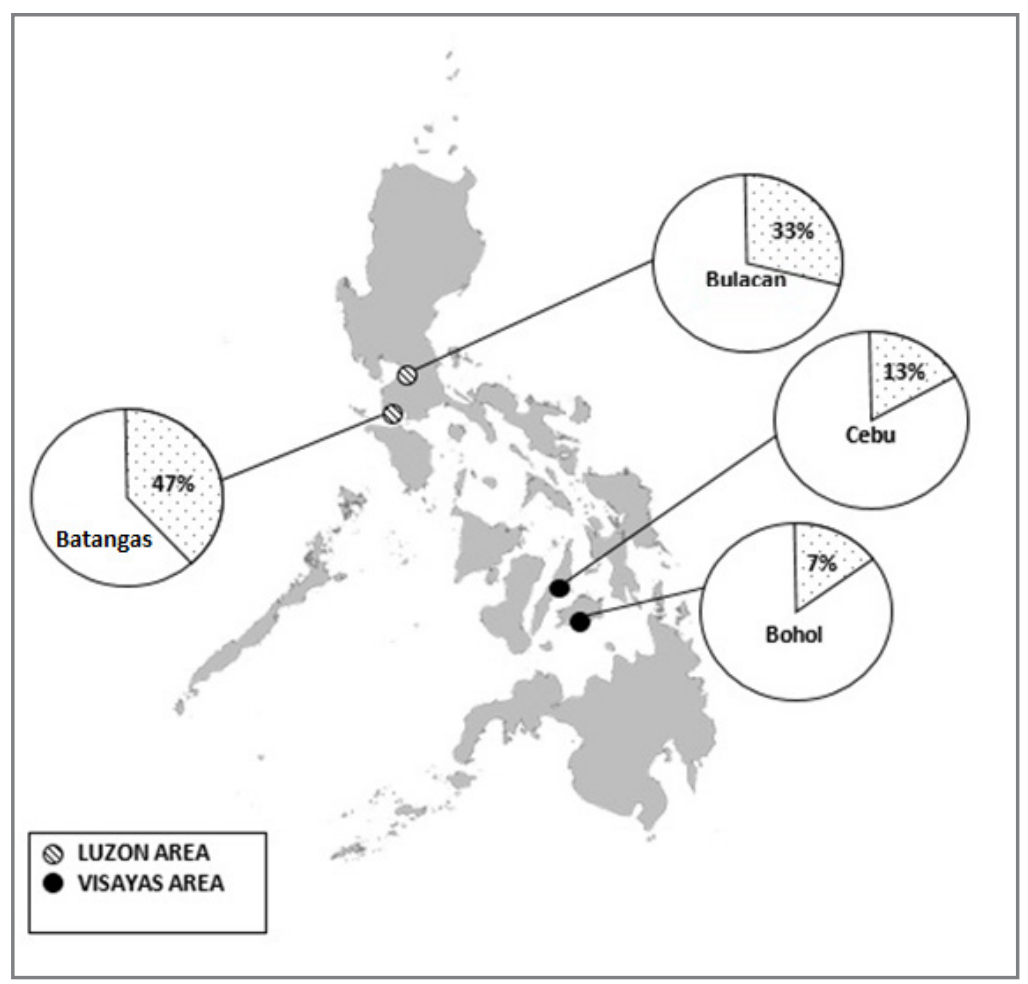

Figure 6. Philippine sampling sites prevalence of Taura Syndrome Virus (TSV).

(Figure 6): Bulacan with 5 out of 15 samples (33\%), Batangas with 7 out of 15 samples (47\%), Bohol with 1 out of 15 samples (7\%), and Cebu with 2 out of 15 samples (13\%). The Batangas samples showed the highest prevalence having a percentage prevalence of $47 \%$ (7 out of 15 samples) that were positive of the infection. As stated in the Quarterly Aquatic Animal Disease Report (Asia-Pacific Region) of NACA, OIE, and FAO for October to December of 2018, there has been no reported case of Taura Syndrome Virus in the Philippines. This is the first record of TSV among L. vannamei population in the Philippines using purposive sampling. RT-PCR revealed a positive product of $\geq 200 \mathrm{bp}$. Phylogenetic analysis supports the hypothesis that TSV isolates have their origins in the Americas (Wertheim et al. 2009) similar to that of WSSV where the spread of the virus has been linked to a common ancestor in Asia (Zwart et al. 2010) and that the Philippine isolate clusters with the Southeast Asian TSV lineage. It is suspected that detection of the virus in the country has been hindered since TSV is RNA-based and there are limited facilities to perform routine detections as compared to DNA-based viruses. Routine surveillance and diagnostics methods must be employed in order to detect other DNA and RNA-based viruses to improve, sustain, and prevent massive losses of the shrimp aquaculture industry.

\section{CON C L US I O N}

In accordance to the corroborative diagnostic criteria set by the World Assembly of Delegates of the OIE in 2017, a combination of molecular and morphological tests was done to confirm the case of TSV presence in L. vannamei in the Philippines. Molecular test using RT-PCR showed positive results for TSV as evident in the amplified $\geq 200$ bp sequence of the TSV genome. Further studies using phylogenetic analysis were done, and BLASTn analysis proved that TSV Philippine isolate is highly similar to other sequences of TSV isolates from other countries. The phylogenetic tree constructed revealed that TSV Philippine isolate is closely related to TSV Taiwan isolate. Consequently, morphological results revealed clinical signs of TSV disease like general redness of the carapace and pleopods and necrotic gill tissue. Shrimps showed an overall pale reddish coloration, have soft shells, and tail fins are distinctly red. Close inspection of the cuticular epithelium in thin appendages revealed epithelial necrosis. The samples from different sites in the country showed positive results for TSV as follows: Bulacan (33\%), Batangas (47\%), Bohol 
(7\%), and Cebu (13\%). The detected prevalence rates of this study comprise a small sample population and with limited areas in the Philippines, namely Bulacan, Batangas, Bohol, and Cebu. TSV prevalence in the Philippines can be deemed not alarming compared with WSSV prevalence in the country.

Further testing in other sites in the country and implementation of mitigation methods and policies to prevent further spread of the viral disease in the country and in the world are recommended. Lastly, further studies, whether pathological signs are due to TSV alone or due to co-infection with other pathogens, is recommended.

\section{A C K N O W L E D G EN T}

This work was funded in part by the Department of Science and Technology-Philippine Council for Agriculture, Aquatic, and Natural Resources Research and Development (DOST-PCAARRD). The researchers would like to thank Dr. Rapeepat Mavichak from Charoen Pokphand Group, Thailand, for providing the positive control of the Taura Syndrome Virus (TSV).

\section{R E F E R E N C E S}

Albaladejo JD, Tapay LM, Migo VP, Alfafara CG, Somga JR, Mayo SL, Miranda RC, Natividad K, Magbanua FO, Itami T, Matsumura M, Nadala EC, Loh PC, Flegel TW editor. 1998. Proceedings to the Special Session on Shrimp Biotechnology, Screening for shrimp viruses in the Philippines, Advances in Shrimp Biotechnology; Bangkok, Thailand. National Center for Genetic Engineering and Biotechnology.

Caipang CMA, Sibonga MFJ, Geduspan JS, Apines-Amar MJS. 2011. Sequence diversity of the infectious hypodermal and hematopoietic necrosis virus (IHHNV) in cultured shrimp populations in the Philippines. AES Bioflux. 3(3): 272-279.

Catap ES, Lavilla-Pitogo CR, Maeno Y, Travina RD. 2003. Occurrence, histopathology, and experimental transmission of hepatopancreatic parvovirus infection in Penaeus monodon postlarvae. Diseases of Aquatic Organisms. 57: 11-17.

Kautsky N, Ronnback P, Tedengren M, Troell M. 2000. Ecosystem perspectives on management of disease in shrimp pond farming. Aquaculture. 191: 145-161.

Lightner D. 1999. The penaeid shrimp viruses TSV, IHHNV, WSSV, and YHV: Current status in the Americas, available diagnostic methods, and management strategies. Journal of Applied Aquaculture. 9(2): 27-52.

Magbanua FO, Natividad KT, Migo VP, Alfafara CG, de la Pena FO, Miranda RO, Albaladejo JD, Nadala ECB, Loh PC, Mahilum-Tapay L. 2000. White Spot Syndrome virus (WSSV) in cultured Penaeus monodon in the Philippines. Dis. Aquat. Org. 42: 77-82.

Maningas MB, Kondo H, Hirono I, Saito-Taki T, Aoki T. 2008. Essential function of transglutaminase and clotting protein in shrimp immunity. Molecular Immunology. 45: 1269-1275.

Natividad KDT, Migo MVP, Albaladejo JD, Magbanua JPV, Nomura N, Matsumura M. 2006. Simultaneous PCR detection of two shrimp viruses (WSSV and MBV) in postlarvae of Penaeus monodon in the Philippines. Aquaculture. 257: 142-149.

[NACA, OIE, FAO] Network of Aquaculture Centers in Asia-Pacific (NACA), World Organization for Animal Health (OIE) Regional Representation for Asia and the Pacific, and Food and Agriculture Organization of the United Nations (FAO). 2019. Quarterly Aquatic Animal Disease Report (Asia and Pacific Region), 2018/4, October December 2018. NACA, Bangkok, Thailand and OIE-RRAP, Tokyo, Japan.

Nunan LM, Poulos BT, Lightner DV. 1998. Reverse transcription polymerase chain reaction (RTPCR) used for the detection of Taura Syndrome Virus (TSV) in experimentally infected shrimp. Dis. Aquat. Org. 34: 87-91.

Phalitakul S, Wongtawatchai J, Sarikaputi M, Viseshakul N. 2006. The molecular detection of Taura syndrome virus emerging with White spot syndrome virus in penaeid shrimps of Thailand. Aquaculture. 260: 79-81.

Sappat A, Jaroenram W, Puthawibool T, Lomas T, Tuantranont A, Kiatpathomchai W. 2011. De- 
tection of shrimp Taura syndrome virus by loop-mediated isothermal amplification using a designed portable multi-channel turbidimeter. Journal of Virological Methods. 175: 141-148.

Tamura K, Stecher G, Peterson D, Filipski A, Kumar S. 2013. MEGA6: Molecular Evolutionary Genetics Analysis version 6.0. Molecular Biology and Evolution. 30: 2725-2729.

Tamura K, Nei M. 1993. Estimation of the number of nucleotide substitutions in the control region of mitochondrial DNA in humans and chimpanzees. Molecular Biology and Evolution. 10: 512526.
Wertheim JO, Tang KFJ, Navarro SA, Lightner DV. 2009. A quick fuse and the emergence of Taura syndrome virus. Virology. 390(2): 324-329.

[OIE] World Organization for Animal Health. 2016. OIE - Manual of Diagnostic Tests for Aquatic Animals 6th Edition. Paris, France: World Organization for Animal Health. 503 p.

Zwart M, Dieu B, Hemerik L, Vlak JM. 2010. Evolutionary trajectory of White Spot Syndrome Virus (WSSV) genome shrinkage during spread in Asia. PLoS One. 5(10): e13400. 